\title{
Farmers Commitment in Maintaining Wetted land Ownership Status in Peri-Urban Area of Yogyakarta
}

\author{
Sudrajat
}

Received: 30102015 / Accepted: 10012015 / Published online: 30062016

๑) 2016 Faculty of Geography UGM and The Indonesian Geographers Association

\begin{abstract}
The existance of wetted land in Peri-urban Yogyakarta can not separated from the farmer's commitment. This research is aimed to analyze farmer's commitment in maintaining wetted land ownership status in Peri-Urban Yogyakarta and to identify its influencing factors. This research is conducted in peri-urban area of Yogyakarta by taking some wettted land's owners who are active in farming, as the respondents. The meaurement of farmer's commitment indicators are done by likert scale. The result indicated that farmers in Peri-urban area of Yogyakarta have low commitment in maintaining wetted land ownership status. Low level of farmer's commitment are reflected from the low commitment to prevent the desire to sell the wetted land, to rent out the wetted land for non-agricultural use and to change the wetted land for non-agricultural use. This research also indicated that the low commitment is also significantly influenced by wetted land price, wetted land location, and its social value.
\end{abstract}

Keywords: farmer's commitment, wetted land ownership,maintain

\begin{abstract}
Abstrak Keberadaan lahan sawah di pinggir kota Yogyakarta tidak telepas dari komitmen petani. Penelitian ini bertujuan untuk menganalisis komitmen petani dalam mempertahankan kepemilikan lahan sawah dan faktor-faktor yang mempengaruhinya. Penelitian ini dilakukan di pinggiran kota Yogyakarta dengan mengambil sejumlah petani pemilik lahan sawah yang akatif melakukan kegiatan usahatani. Pengukuran indikator komitmen petani menggunakan skala likerts. Hasil penelitian menemukan bahwa petani di Pinggiran Kota Yogyakarta memiliki komitmen yang rendah dalam mempertahankan kepemilikan lahan sawahnya. Rendahnya komitmen petani tersebut, tercermin dari komitmen yang rendah dalam mencegah keinginan untuk menjual lahan sawah, mencegah keinginan untuk menyewakan lahan sawah untuk penggunaan non pertanian dan mencegah keinginan untuk merubah lahan sawah menjadi lahan non pertanian. Hasil penelitian ini juga menemukan bahwa komitmen petani sangat dipengaruhi secara signifikan oleh faktor harga lahan sawah, lokasi lahan sawah dan nilai sosial lahan sawah.
\end{abstract}

Kata kunci: komimten petani,lahan sawah, maintain.

\section{Introduction}

The city development of Yogyakarta toward Sleman and Bantul gave impact in the increasing of the competition for land become out of control [Sudrajat, 2010]. Whereas on the one hand there is an urge for agriculture to meet the food needs and on the other hand there are interests of meeting the needs of the room for a variety of uses in agriculture. Competition for land is not just happening in Peri-urban areas but has spread to rural areas, so that farmers in rural communities also felt an increasing demand for land [Ilham, 2003].

Increasing demand for land has led to the increasing of the competition for land, impacting on changes in the economic value of land. As a result, the higher value of non-agricultural land has led to the use of land for agriculture is always defeated by the non-agricultural designation such as land for settlement or industrial and other infrastructure [Nasoetion and Winoto, 1996]. Similarly, according to [Kurnianti et al, 2015] the

Sudrajat

Faculty of Geography, Universitas Gadjah Mada, Indonesia Email: sudrajatgeo@yahoo.com increasing demand of land for those economic activities cause land use changes. Agricultural land (wetted land) is the most land use into other land use especially for settlements.

On the one hand, the increasing pressure of urban sprawl on agricultural lands in some particular wetted land has responded positively by the majority of farmers by increasing the intensity of crop production in response to increased demand for food. On the other hand, increasing demand of land for non-agricultural use has led to the loss of the commitment of farmers to farm with all kinds of activities. The decreasing of farmer's commitment reflected in the farmer's behavior, morale, and motivation to maintain agricultural land ownership [Yunus, 2001]. The most obvious impact of farmer's commitment lost on agricultural land is in the increasing number of farmers who convert their land to non-agricultural land, either individually or collectively [Jamal, 2001; Tajering 2005; Irawan et al., 2005]

The decreasing of the farmer's commitment on agricultural land is not only caused by the commercialization of agricultural land due to the high demand for non-agricultural use, but also due to the lack 
of knowledge of farmers to multifunctional agriculture [Sudrajat, 2010]. Even though, land is a natural resource that has a multifunctional value for human life and the environment. The multifunctional value of agricultural land can be seen from various perspectives such as in terms of economic, social, cultural, and environmental [Rahmanto at al., 2006; Simatupan dan Irawan, 2002; Jamal, 2001; Sudrajat 2010].

The changes of farmer's commitment to maintain their agricultural land is reflected by the conversion from agricultural land to non-agricultural land. In fact, there is a tendency of farmers who do the farming activities under the control of the economies of scale tend to sell the land to another party, so that economic reasons are behind the conversion or diversion of agricultural land use to non-agricultural [Ilham 2003; Syafa'at et al., 2001]. Moreover, if the rate of profit (land rent) derived from non-agricultural land rent is higher than that obtained from the agricultural sector, the conversion of land by an individual either sporadically or in bulk by the developer will be difficult to stop [Rusastra and Bhudi, 1997]. Thus, the loss of agricultural land is directly or indirectly affecting the availability of local food, so that the level of food security will be increasingly vulnerable.

The increasingly weak commitment of farmer to the ownership of wetted land is not only resulted from commersialization of land due to various pressures for a non-agricultural interest, but also resulted from the lack of support to agricultural sector. If the symptom cannot be treated immediately, it can be expected that in the future more farmers will sell, change, or rent out their wetted land for non-agricultural activities instead of preserve it as agricultural land. Moreover, it is possible that the remaining wetted land will be used up because farmers are generally no longer interested to the wetted land with all forms of agricultural activity. Based on those problems, the objectives of this paper are to find out farmer's commitment in maintaining wetted and ownership status and to analyze its influencing factors.

\section{The Methods}

This study used survey method as its main method, which collected a number of samples from population. The study was conducted in peri-urban Areas of Yogyakarta City by taking several villages as samples of the research location. Villages selected as samples of the research location were two villages in areas of Sleman Regency: Trihanggo Village in Gamping Subdistrict and Sinduadi Village in Mlati Subdistrict, and three villages in areas of Bantul Regency: Tirtonirmolo Village in Kasihan Subdistrict, Bangunharjo Village in Sewon Subdistrict, and Tamanan Village in Banguntapan Subdistrict. More detail of the reseach location in Periurban Yogyakarta can be seen in Figure 1.

The data used consists of primary and secondary data. The primary data were directly collected from field through interview and FGD as well as in-depth interview with some farmers, social figures, and village government apparatuses. The secondary data were

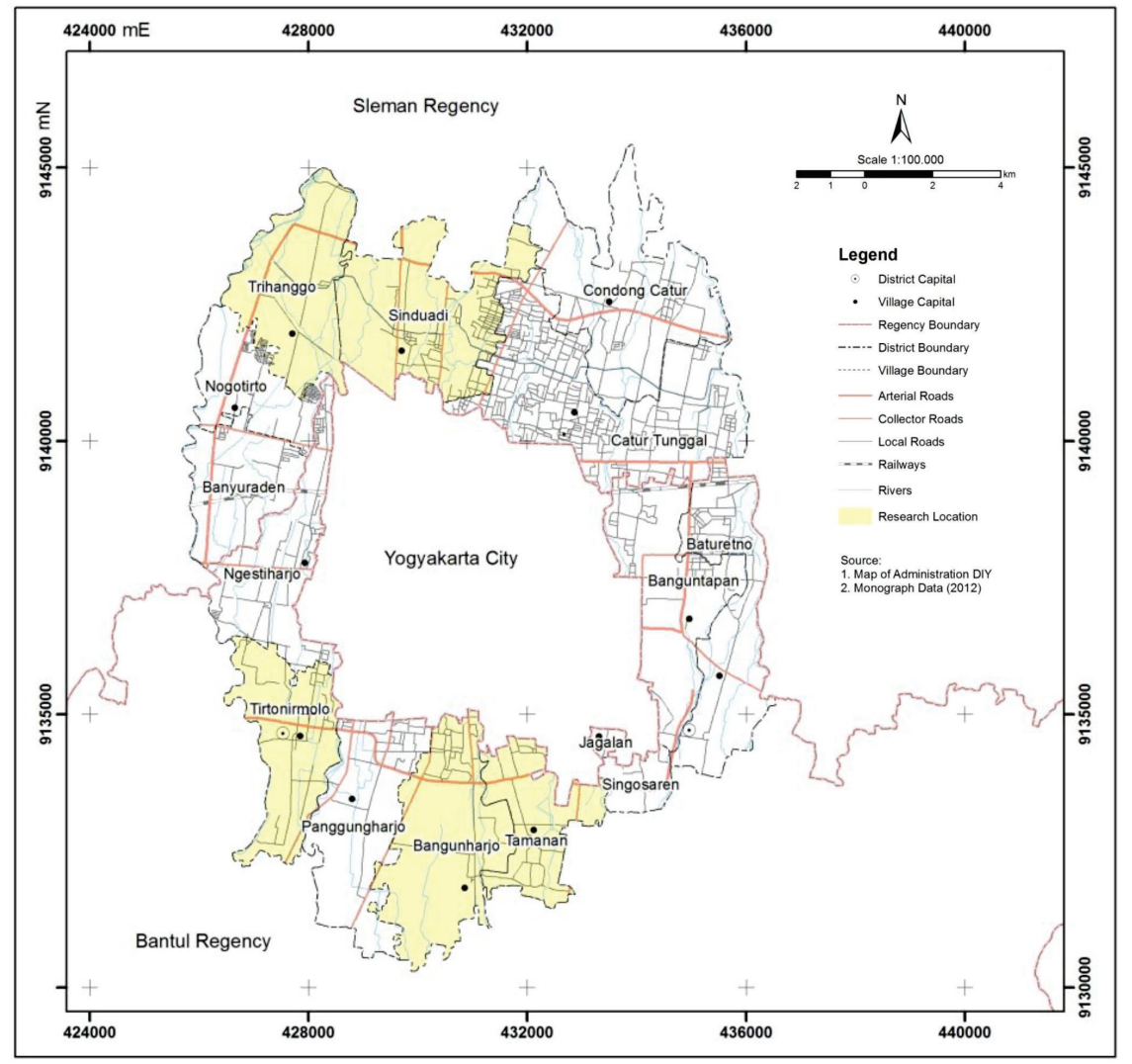

Figure 1. Location at Research Area in Peri-Urban at Yogyakarta 
collected through institutional study in several relevant instances. Population in the study was farmers living in the research location, while the samples were farmers with the ownership of wetted land and actively do agricultural activities. The samples were taken from each village proportionally using random sampling technique. The testing of validity was done by using a product moment correlation and reliability test with the alpha (a) coefficient value criteria.

The measurement of farmer's commitment to the ownership of agricultural land was done using three indicators: first, indicator related to the commitment of farmer to prevent the desire of selling wetted land they owned; second, indicator related to the commitment of farmer to prevent the desire of renting out wetted land that will be used for non-agricultural purpose; and third, indicator related to the commitment of farmer to prevent the desire of changing wetted land for nonagricultural use. The first was explained in nine items of statement; the second was explained in five items of statement; and the third was explained in five items of statement.

The measurement of farmer's commitment in maintaining wetted land ownership is done by likerts scale. The data obtained through a valid and reliable questionnaire which already passed the validity and reliability test. Each alternative response was weighted on a likerts scale or score. Score calculation is done by summing the score of each variable which given by a respondent then categorized in several category.

The calculation of scores was carried out by using two kinds of score: the largest score per respondentt that can be given by a respondent and the total score of respondents. Scores given by respondents from each of the statement items were summed up. The scores of assessment consisted of maximum score, minimum score, median, and quartile I and quartile III. If the total scores of field data from respondents ranged from:

Lower to Q1 = very negative/very low commitment

$>\mathrm{Q} 1$ to $<\mathrm{Q} 2=$ negative/low commitment

$>$ Q2 to $<$ Q3 = positive/high commitment

$>$ Q3 = positive/very high commitment

In addition, quantitative analysis of the categorization scores was done in three groups: low commitment, middle commitment and high commitment. The Qualitative analysis is done by descibing field survey and FGD results, while quantitative analysis is done with logistic multinomial regression.

\section{Result and Discussion}

\section{General profile of the research location}

Yogyakarta City is physically rounded by ring road, connecting road which connecting the outside of urban to peri-urban areas. The existence of ring road influences land use pattern in peri-urban areas with different intensity. The peri-urban areas can be recognized by observing the integrated orientation of urban and rural land use. The form of urban land use was recognized by non-agriculture-oriented land use, while rural land use was recognized by agricultureoriented land use. Peri-urban areas with mostly initial pressures over agricultural land were the peri-urban areas which directly adjacent to Yogyakarta City. Agriculture and non-agriculture land use (wetted land) in reseach location can be seen in Table 1.

Table 1. Land use In Reseach Location

\begin{tabular}{lrrrr}
\hline Village & \multicolumn{4}{c}{ Land use (hectare) } \\
\hline $\begin{array}{l}\text { Agriculture } \\
\text { (Wetted }\end{array}$ & $\begin{array}{l}\text { Per- } \\
\text { centage } \\
\text { land) }\end{array}$ & $\begin{array}{l}\text { Non-Agri- } \\
\text { cultural and } \\
\text { Other land }\end{array}$ & Percentage (\%) \\
\hline Trihanggo & 334.7 & 21.0 & 227.3 & 17.8 \\
Sinduadi & 147.0 & 9.2 & 597.0 & 46.7 \\
$\begin{array}{l}\text { Tirtonirm- } \\
\text { olo }\end{array}$ & 405.5 & 25.4 & 107.5 & 8.4 \\
Bangunharjo & 465.0 & 29.2 & 214.0 & 16.7 \\
Tamanan & 241.9 & 15.2 & 133.1 & 10.4 \\
Total & $1,594.2$ & 100,0 & 1.278 .9 & 100,0 \\
\hline Source: Monograph Data, 2012 & & & \\
\hline
\end{tabular}

Table 1 shows at a macro level, land use in the research location could be differentiated into two groups agricultural land and non-agricultural land. More detail of the agriculture land use (wetted land) in reseach location can be seen in Figure 2.

Figure 2 shows one of the forms of agricultural land use was wetted land. The wetted land in the research location was dominantly used for agricultural purpose with sufficiently various widths of land. The wetted land in the five research villages were continuously under the pressures of urban area, so that the ownership of such land continuously decreases annually. Bangunharjo village is one of the villages with the widest width of land, while those with narrowest width of land was Sinduadi Village. The narrow-wide area of wetted land in Sinduadi Village occurred because it sufferred from the changing in function, from agricultural to nonagricultural land. On the contrary, Tirtonirmolo village is a village with relatively low non-agricultural land use, while the wetted land use is still sufficiently wide (Figure 3). More detail of the non-agriculture land use in reseach location can be seen in Figure 3.

By the difference it means difference in pressure over wetted land resulted from the growth of population and the need for space for socio-economic facilities. The increasing number of population resulted in the growing demand for wetted land for living, settlement, industry, service, trade, and so forth.

\section{Socio-demographic profile of farmer household}

Socio-demographic profile of farmer household is a general description on the characteristics of farmer household, including the aspects of age, 


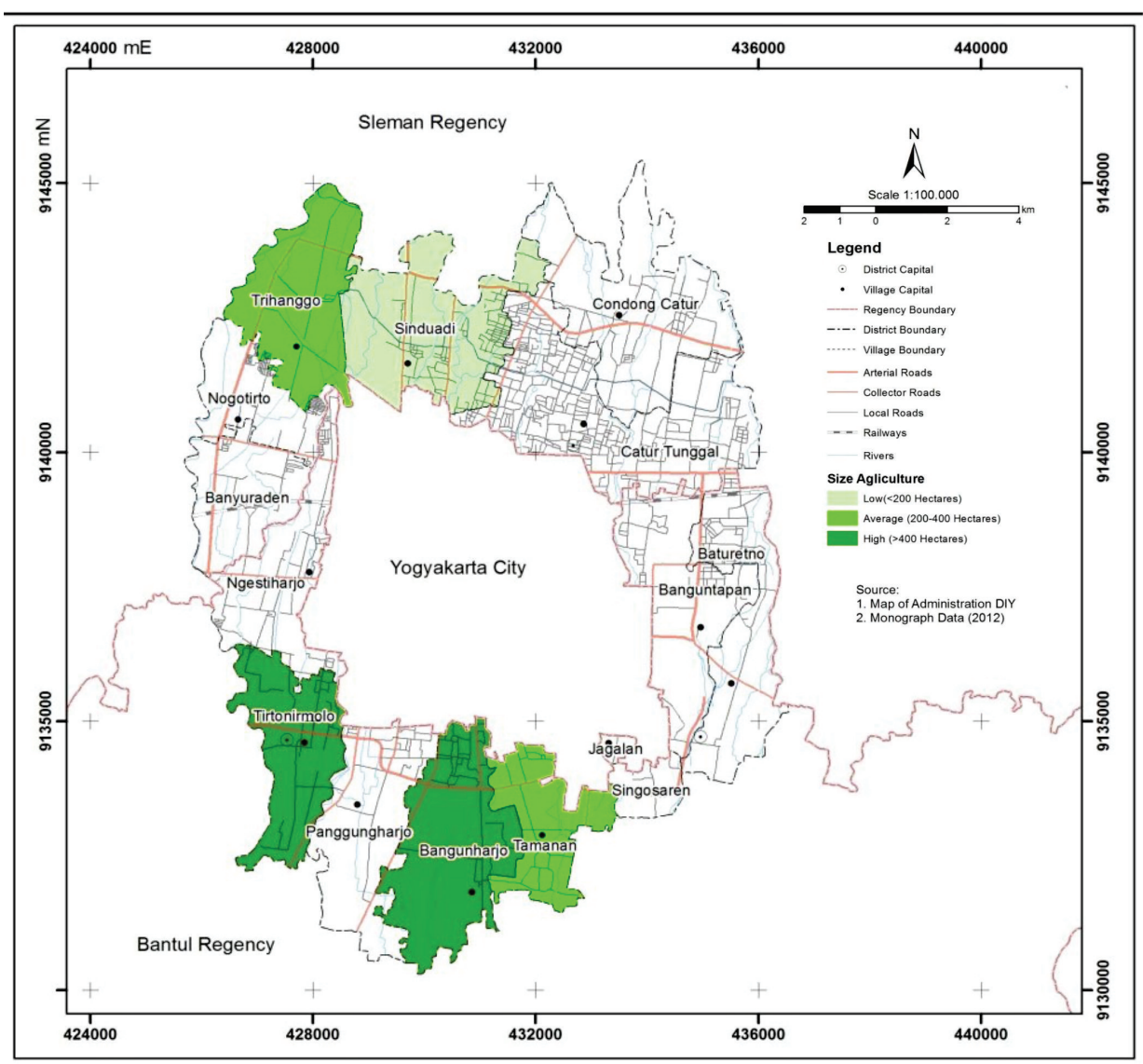

Figure 2. Location at Research Area in Agriculture Land Use

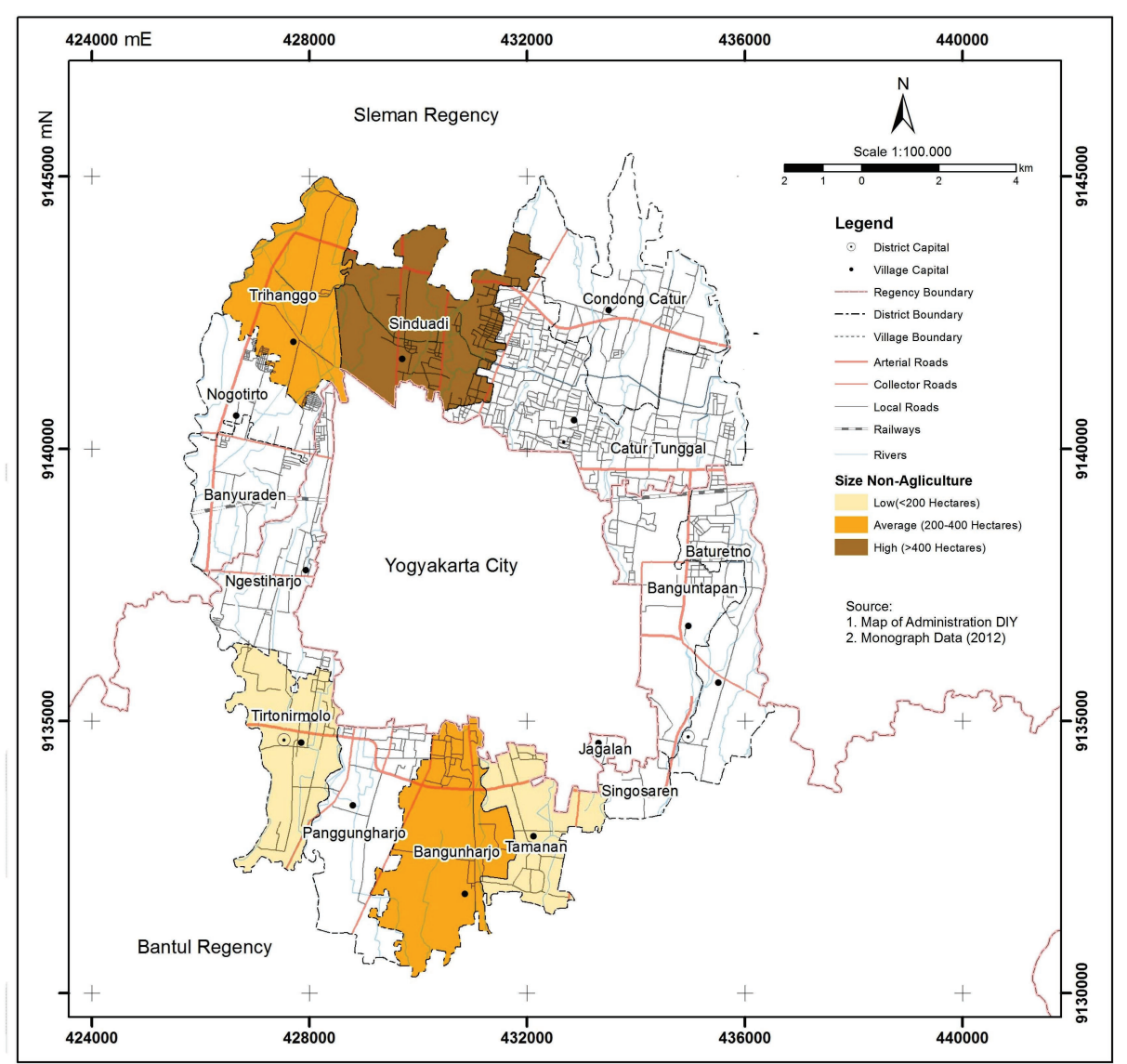

Figure 3. Location at Research Non-Agriculture Land Use 
farming experience, education, social value of land, and the number of household member working in agriculture. Result of the study shows that farmers who actively involved in agricultural activities were mostly categorized in productive age, but those in nonproductive one was also sufficiently large. In fact, there was a tendency that their involvement in agricultural activities was dominated by the population of 50 years old. The phenomenon shows that the regeneration of farmers was very pitiable as a result of the increased education of farmer family member, the decreased width of owned agricultural land, and the increased opportunity of non-agricultural work. If the symptom continuously occurs, some more serious problems will appear. It is concerned that if the agricultural sector is dominated by labors of upper than 50 years old, years later the availability of agricultural labor will be scarce, so agricultural activities in the research location will be lost.

Result of the study indicates also that education level of the head of farmer household was largely at low level, i.e.: elementary school (ES), or even no ES graduation, while those with education at junior and senior high school level was very small. The symptom indicates that farmers involved in wetted land-based agricultural activities were those with the low level of education. If the symptom continuously occurs, it is so pitiable. Who are willing to work as farmers in agricultural sector? However the increasing in education of farmer's family member was not accompanied by the desire of continuing to work in agricultural sector. After being equipped with the high level of education, they tend to choose working in other sectors. The lack of interest to work in agriculture among farmer's family members working in agricultural sector could be seen from the low household members working in agricultural areas: mostly $<2$ people and only very small with household members working in agricultural sector of $>2$ people.

The condition shows that agricultural activities was no longer interesting for household members due to reasons as follows: limited work opportunities in agricultural sector for those with the higher level of education; agricultural sector cannot generally provide immediate income; agricultural works have many risks; income gained from agricultural sector was lower than expected one; and the low level of social status and work comfort due to slum and dirty work in agricultural sector. Even by assumption that no development of work opportunity and the low level of productivity in agricultural sector, many relatively educated young labors go to urban areas for work in non-agricultural sector. If the symptom continously occurs, the lack of labor will, of course, occur in agricultural sector, resulting in problems, i.e. difficulty in recruiting new labors for agricultural works.

\section{Economic profile of farmer household}

The economic profile of farmer household is a description of economic condition of household and economic activities done by the head of household. The economic profile and economic activities include the total ownership of wetted land, the ownership of wetted land, income from the use of wetted land, the types of side jobs, and total income of the head of household. Result of the study indicates that farmers in agricultural area own agricultural land with the width of 0.26 ha in average. The narrow width of farmer's land ownership in the research location occurs as a result of the low level of land ownership system based on renting or sharing profit. Most wetted lands owned by farmers were cultivated by themselves because their wetted land mostly only 0.25 ha in wide. The low level of wetted land ownership in the research location has impact on the farm income of wetted land. Result of the study indicates that the average income of farmer from agricultural sector in wetted land was only IDR315,433.00 monthly.

The insufficiency of income as a result of the wetted land use frequently encouraged many heads of household to do work diversification through side jobs. Result of the study indicates that $51.2 \%$ of the head of household in the research location have sufficiently variative side jobs and the remaining was $48.2 \%$ with no side job. The types of side job was largely as rough labor, seller, farming labor, village chicken breeder, and building labor/craftsman. The side jobs were done as a concequence of inadequacy in income for meeting the need of household from the main job. Usually, the side jobs were done by the heads of household when they are waiting for crop harvest or in leisure times. Income gained from the side jobs given a great contribution to additional income of the head of household. It can be seen from the increase of household income: farmer with income >IDR 500,000.00 per month increased approximately $45.6 \%$. In fact, before the additional income of side job, the number of farmers with income $>$ IDR 500,000.00 per month was only $23.2 \%$. It indicates that the side jobs done by the heads of farmer household has played a great role in increasing the total income of household.

\section{The Profile Of Farmer's Household Perception To Wetted land Social Value}

The increasing of wetted land demand for nonagricultural the use in Peri-urban Yogyakarta has resulted to the changing perception of farmers on the social value of wetted land. The change in perception is strongly associated with the diminishing of how farmers seen on the value of social, multifunctional wetted land. In these conditions the farmer has overlooked the important value of land from the side of social, but more concerned of looking at the economic value it generates. Distribution of farmer's perception of the social value of wetted land in more detail can be seen in Table 2. 
Table 2. Farmer's Perception of The Social Values of Wetland In Suburbs Yogyakarta

\begin{tabular}{lrr}
\hline farmer's Perception & Frequency & \multicolumn{2}{c}{$\begin{array}{l}\text { Percentage } \\
(\%)\end{array}$} \\
\hline $\begin{array}{l}\text { Farmer's Perception: Low } \\
\text { (Score <19) }\end{array}$ & 101.0 & 63.1 \\
$\begin{array}{l}\text { Farmer's Perseption: } \\
\text { Average (Score 19-30) }\end{array}$ & 31 & 19.4 \\
$\begin{array}{l}\text { Farmer's Perseption: } \\
\text { High (Score >30) }\end{array}$ & 28 & 17.5 \\
& & \\
& 160 & 100.00 \\
\hline
\end{tabular}

Source: Primery Data , 2013

Table 2 shows that the majority (63.1\%) of farmers on Peri-urban of Yogyakarta have a low perception of the social values of wetted land, while the perception of the category of medium just as much as $19.4 \%$, and the remaining $17.5 \%$ still have a perception in high category. The large number of farmers who have a low persepsion of social value of wetted land implies that the farmers in Peri-urban Yogyakarta are no longer seen wetted land as resource which can give them social benefits. This is mainly related to the changing of their point of view that wetted land the symbol of household wealth. Selling wetted ands are no longer consider as an embarrassing and taboo actions, employing neighbors, relatives or other persons on his farm are no longer felt as a homage from their communities; wetted land are no longer seen as the prevention the increasing of labor mobility flows from villages to cities; maintaining the wetted land heritage are no longer seen as one form of execute the mandate or testament from the ancestor; wetted land are no longer seen as the source of a sense of togetherness or mutual cooperation among the farmers; wetted land is no longer deemed to gives pride for farmers; and there was no longer view considers that when the farmer died and did not bequeath land, it will be regarded as less honorable farmer. The low perception of farmers on the social value of wetted land in turn encourages the farmers to commercialize his farm.

\section{The Commitment of Farmer In Maintaining Wetted land Ownership Status}

In the view of physical aspect, wetted lands in PeriUrban Areas of Yogyakarta City are undergone changing in land function. Therefore, it can be assured that farmers are undergone changeing in social, economic, and cultural aspects. One of the changes among farmers was reflected from their commitment in maintaining wetted land ownership status. The commitment is one of the reflections of their commitment in maintaining wetted land ownership status. It was measured by three forms of commitment: first, the commitment of farmer to prevent the desire of selling the wetted land; second, the commitment of farmer to prevent the desire of renting out the wetted land that will be used for non-agricultural purpose; third, the commitment of farmer to prevent the desire of changing the wetted land into non-agricultural land. Based on it, the farmers commitment in maintaining wetted land ownership status was manifested in actions taken by farmers to make a contract with wetted land they owned by performing actions as follows: to prevent the desire of renting out the wetted land that will be used for non-agricultural purpose and to prevent the desire of changing the wetted land for non-agricultural purpose.

Result of the study in Table 3 shows the total scores of the three indicators were given by 5,980 respondents. Value of the total scores ranged from Q1 with value of 4,750 and Q2 with value of 7,125. Based on the value of total scores, the farmer's commitment in maintaining wetted land ownership status was included in negative category or low commitment. It means that farmers in the research location have entirely a negative tendency or low commitment in maintaining wetted land ownership status. In other words, farmers in the research location did not do actions for preventing the desire of selling the wetted land, that of renting out the wetted land that will be used for non-agricultural purpose, and that of changing the wetted land for nonagricultural use.

Table 3. Score Commitment in Maintaining Wetted land Ownership Status

\begin{tabular}{lr}
\hline Score Calculation & Value \\
\hline Lower limit (L) & 2,375 \\
Q1(Quartile 1) & 4,750 \\
Q2 (Median 2) & 7,125 \\
Q3 (Quartile 3) & 9,500 \\
Upper Limit (U) & 11,875 \\
Score total from respondents & 5,980 \\
\hline
\end{tabular}

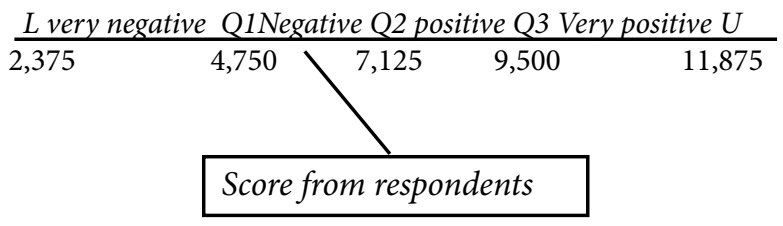

The low commitment of farmers in maintaining wetted land ownership status occured as a result of the lack of support in agricultural activities. According to some farmers when FGD and indepth interview was hold, the reasons why the farmers did not want to defend the ownership of wetted land, among others, were: they feel tired up as farmers with a low level of income; they want to invest in non-agricultural sector; wetted land was frequently vulnerable to household waste at a rainy season; they suffered difficulty in labor recruitment; and wetted land was generally located in the midst of settlement. Nevertheloss, farmer's commitment in maintaining wetted land ownership status will be so variative if it 
is individually seen from all the items of statement in each indicator. Therefore, in the next discussion in particular, the distribution of answers they given could be seen from each item of statement in each indicator.

\section{The commitment of Farmer to Prevent the Desire of Selling Wetted land}

The commitment of farmer to prevent the desire of selling the wetted land can not be separated from the influencing factors. Farmer's desire to sell the land could be originated from something inside the farmers so they were voluntary and that outside enforcing them to sell the owned wetted land. The commitment of farmer to prevent the desire of selling wetted land was the first indicator used to measure the commitment of farmer to the ownership of wetted land. One of the manifestations for the commitment of farmer to prevent the desire of selling the wetted land was actions done by them to prevent the desire of selling the owned wetted land. In fact, the actions done by them include: always to reminder their friends, neighbors, and relatives for not selling their wetted land, despite the continually growing demand for the wetted land for non-agricultural purpose; to promise the members of family to inherith the wetted land to their heirs as carried out by previous ancestors; to avoid information on development of the price of wetted land in order that they were not interested to sell the wetted land; to create awareness among the members of family that the wetted land has many functions (social, economic and environmental values) that should be preserved; to reject any peoples persuading to sell the wetted land although it will be bought with extremely high price, both sold individually and collectively; to make resistance against peoples forcing or intimidating to sell the wetted land; to preserve and conserve the wetted land because it is one of the main familial livelihood sources; and to avoid the desire of selling the wetted land despite the familial needs to be immediately met. All the nine forms of action that should be done by farmers can be manifestation of the commitment of farmer to prevent the desire of selling the wetted land.

Result of the study in Table 4 shows the total scores of all the nine items of statement were given by 2,499 respondents. The values ranged from Q1 with the value of 2,250 to Q2 with the value of 3,375. Based on the value, farmers in the research location had negative tendency or low commitment to prevent the desire of selling the wetted land. It means that they did not do actions to prevent the desire of selling the wetted land. Consequently, those in the research location will be easy to release the owned wetted land through the selling-buying system. The farmers' easiness to release the wetted land could not be separated from their interest to the ravishing price of wetted land due to the high level of land demand for non-agricultural use.

The low commitment of farmer to prevent the desire of selling the wetted land was seen from all the items of statement given by respondents, which were concentrated to the "disagree" (disagree and greatly disagree) answers with the highest percentage of $84.8 \%$ and the lowest one of $66.4 \%$, while those with the "agree" (agree and greatly agree) answers had the highest percentage of $28.6 \%$ and the lowest one of $8.8 \%$ and those with the "neutral" answers had the highest one of $17.0 \%$ and the lowest one of $2.4 \%$. In the 4 th and 8th items of statement, the respondents' answer was largely concentrated to the "agree" (agree and greatly agree) answers with the highest percentage of $72.0 \%$, and those with the "disagree" (disagree and greatly disagree) answers had the highest percentage of $28 \%$ and the highest percentage for the "neutral" answer was $10.4 \%$. The condition shows that individually farmers in the research location did not do many actions to prevent the desire of selling the wetted land.

Table 4. Score Commitment to Prevent the Desire of Selling The Wetland

\begin{tabular}{ll}
\hline Score Calculation & Value \\
\hline Lower limit (L) & 1,125 \\
Q1(Quartile 1) & 2,250 \\
Q2 (Median 2) & 3,375 \\
Q3 (Quartile 3) & 4,500 \\
Upper Limit (U) & 5,625 \\
Score total from respondents & 2,949 \\
\hline
\end{tabular}

$L$ Very negative Q1 Negative Q2 Positive Q3 Very positive $U$

\begin{tabular}{c}
\hline$, 125 \searrow^{3,375} 4,500$ \\
\\
Score from respondents 5,980
\end{tabular}

According to some farmers when FGD and indepth interview were carried out, farmers' reason for not preventing the desire of selling the wetted land was due to the environment condition of wetted land increasingly less favor of their life with the increasing number of new settlement. Farmers in the condition felt difficulties, particularly related to labors, irrigation, waste from settlement, and so on. In fact, the price of wetted land around the research location continously increased as a consequence of the growing demand of wetted land for non-agricultural use.

\section{The Commitment of Farmer to Prevent the Desire of Renting Out the Wetted land}

Change in the economic structure of peri-urban area due to the development of Yogyakarta City has great impacts on change in the economic value of land. In general, in peri-urban areas the growing demand of land for non-agricultural use will be rapid compared to the growing demand of land for agricultural use, so the economic value of agricultural land was much lower than of non-agricultural one. The higher economic 
value of land use in non-agricultural activities such as for settlement, trade, service, and industry compared to that for agricultural activities resulted in the change of wetled and function. In such condition, farmers will be more interested to rent out their wetted land for nonagricultural use compared to survive in agriculture sector. Change in perspective in economic orientation on the wetted land caused change in the thinking pattern of farmers in maintaining the ownership of weted land.

The commitment of farmer to prevent the desire of renting out the wetted land for non-agricultural use was a second indicator to measure the commitment of farmer to the ownership of wetted land. The manifestation of the commitment was actions done by them to prevent the desire of renting out the wetted land for nonagricultural use. In fact, the actions done by farmers in preventing the desire of renting out the land were as follows : always rejecting people that will rent the wetted land for non-agricultural use, both partially or wholly; trying to make the wetted land difficult for change into non-agricultural one, so people were not interested to rent for non-agricultural use; reminding members of family, friends, neighbors, and relatives for not renting out the wetted land for non-agricultural use, so it did not disturb the surrounding wetted land; implanting consciousness among members of family that renting out the wetted land for non-agricultural land will make difficulty in returning the function of wetted land as previous one; and trying to increase the production of wetted land in order that income from the wetted land was always higher than that from renting out the land for non-agricultural use. All the five actions done by farmers were the manifestation of the commitment of farmer to prevent the desire of renting out the wetted land that will be used for non-agricultural activities.

Result of the study in Table 5 shows the total scores of the five items of statement was given by 1,568 respondents. The values ranged from Q1 with value of 1,250 to Q2 with value of 2,500. Based on the values, farmers in the research location had negative perspectives and low commitment to prevent the desire of renting out the wetted land that will be used for nonagricultural activities. The negative perspectives or low commitment indicates that farmers in the research location did no longer actions leading to the efforts of preventing the desire of renting out the wetted land for non-agricultural use. Thus, farmers will like if the wetted land was rented by other people for non-agricultural activities because it will be economically profitable.

The tendency of the low commitment of farmers to prevent the desire of renting out the wetted land for non-agricultural use indicates that answers given by respondents in the five items of statement were largely concentrated to the "disagree" (disagree and greatly disagree) answers with the highest percentage of $80.8 \%$ and the lowest percentage of $62.4 \%$. Meanwhile, for respondents with the "agree" (agree and greatly agree) answers for all the items of statement the highest percentage was $33.6 \%$ and the lowest one was $14.4 \%$, while for the remaining with the "neutral" answers, the highest was $6.4 \%$ and the lowest $4.0 \%$. Based on the results, it can be said that farmers in the research location will like if the wetted land was rented by other people that will use it for non-agricultural activities.

Table 5. Score Commitment to Prevent the Desire of Renting Out The Wetted land

\begin{tabular}{lr}
\hline Score Calculation & Value \\
\hline Lower limit (L) & 625 \\
Q1(Quartile 1) & 1,250 \\
Q2 (Median 2) & 1,875 \\
Q3 (Quartile 3) & 2,500 \\
Upper Limit (U) & 3,125 \\
Score total from respondents & 1,568 \\
\hline
\end{tabular}

$L$ Very negative Q1 Negative Q2 Positive Q3 Very positive $U$

\begin{tabular}{|c|c|c|c|}
\hline$\overline{625}$ & 1,250 & 1,875 & 2,500 \\
\hline
\end{tabular}

According to some farmers when FGD and indepth interview were done, farmers' reasons for deciding that the wetted land should be rented for non-agricultural use were: the economically profitable price of rented land compared to that for agricultural use. In fact, many buildings, for settlement and non-settlement, were largely established around the wetted land, so agricultural activities were recessive. In addition, by renting out the wetted land for non-agricultural use, they feels to be helped by the renter in changing the wetted land into agricultural land without spending costs. The symptom occured as a result of the productivity of wetted land or economic value produced by the economically less profitable use of wetted land, while if it was rented out for non-agricultural use, it will give larger profit gain. Based on the result, it can be said that many farmers did not do actions to prevent the renting out of wetted land.

\section{The Commitment of Farmer to Prevent the Desire of Changing Wetted land Function}

Farmer's decision to change wetted land function to be non-agricultural land can not be separated from their motive to meet the need for residence, increasing income by the transfer of work, the pressure of familial member, and the condition of wetted land that is so impossible to cultivate agriculture. However, for farmers with high dependence on agricultural land they will have the relatively low desire of changing the wetted land function compared to those with entire dependence on wetted land. It occurs because for farmers whose fully dependent on wetted land regarded wetted land as their source of livelihood, which if it was changed, they would lose their prior income. Such farmer did usually have a sufficient capital for 
investment in non-agricultural sector and did not have adequate skills to work in non-agricultural sector, so they will remain to survive with their own wetted land. If the environment of wetted land has increasingly been pressured by the non-agricultural activities, they will only sell their wetted land, then buying wetted land in other rural areas with relatively cheaper price. Different from farmers whose fully dependent on the wetted land, the other groups of farmers have other job in nonagricultural sector; so they have sufficient capital and expert in non-agricultural field and will be easier to do the transfer of wetted land function by themselves.

The commitment of farmer to prevent the desire of changing the wetted land to be non-agricultural land was the third indicator to measure the commitment of farmer to the ownership of wetted land. The manifestations of the commitments are actions done by them to prevent the desire of changing the wetlted and into non-agricultural land. Actions they did to prevent the desire of changing the land were: trying to avoid building house in wetted land; trying to preserve the wetted land, so it is difficult to be changed into non-agricultural land; implanting values among the members of family in order that they did not change the wetted land into non-agricultural land; trying to be still bound to the wetted land by not seeking other job in non-agricultural sectors; and trying to avoid desire to build business places in wetted land although the location is very strategic. All the five actions the farmer did were the manifestations of the commitment of farmer to prevent the desire of changing the wetted land into non-agricultural land.

Result of the study as seen in Table 6 shows the total scores of the five items of statement were given by 1,463 respondents. The values ranged from Q1 with value of 1,250 to Q2 with value of 1,875 . Based on the value, farmers in the research location have negative opinion or low commitment to prevent the desire of changing the wetted land into non-agricultural land. It means that the farmers were no longer did actions to prevent the desire of changing the wetted land into non-agricultural one. In other words, most of farmers in the research locarion had the desire of changing the wetted land for nonagricultural use by preserving their own wetted land.

The low commitment of farmers to prevent the desire of changing the wetted land into non-agricultural one was seen individually from all answers given by the respondents for all the items of statement. They were largely concentrated to the "disagree" (disagree and greatly disagree) answers with highest percentage of $83.2 \%$ and lowest one of $70.4 \%$. Even in statements related to the efforts of avoiding to build business place in wetted land, number of farmers with "greatly disagree" was $22.4 \%$. Meanwhile, farmers with the "agree" (agree and greatly disagree) answers from each highest statement of $27.2 \%$ and each lowest one of $13.6 \%$, and those with "neutral" answer from all the highest statements was $8.0 \%$ and lowest one was $2.4 \%$. The phenomenon describes that farmers in the research location did not do actions referring to the efforts of preventing to change the wetted land into non-agricultural land.

The low commitment of farmers to prevent the desire of changing the wetted land into non-agricultural one was seen individually from all answers given by the respondents for all the items of statement. They were largely concentrated to the "disagree" (disagree and greatly disagree) answers with highest percentage of $83.2 \%$ and lowest one of $70.4 \%$. Even in statements related to the efforts of avoiding to build business place in wetted land, number of farmers with "greatly disagree" was $22.4 \%$. Meanwhile, farmers with the "agree" (agree and greatly disagree) answers from each highest statement of $27.2 \%$ and each lowest one of $13.6 \%$, and those with "neutral" answer from all the highest statements was $8.0 \%$ and lowest one was $2.4 \%$. The phenomenon describes that farmers in the research location did not do actions referring to the efforts of preventing to change the wetted land into non-agricultural land.

Table 6. Score of Commitment to Prevent the Desire of Changing The Wetted land

\begin{tabular}{ll}
\hline Score Calculation & Value \\
\hline 1.Lower limit (L) & 625 \\
2.Q1(Quartile 1) & 1,250 \\
3.Q2 (Median 2) & 1,875 \\
4.Q3 (Quartile 3) & 2,500 \\
5. Upper Limit (U) & 3,125 \\
Score total from respondents & 1,463 \\
\hline
\end{tabular}

L very negative Q1 Negative Q2 Positive Q3 Very Positive $U$

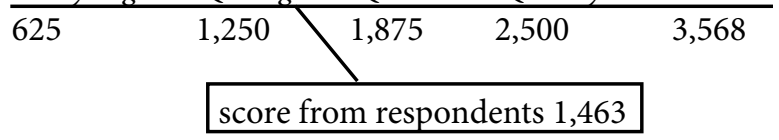

According to several farmers when FGD and in-depth interview were done, it is revealed that the desire of farmers to change the wetted land into nonagricultural land could not be separated from farmers' motive to fullfil the need for residence, to increase income through the transfer of business, pressure of familial member, and the condition of wetted land which was impossible for agricultural sector.

\section{Factors Influencing the Commitment of Farmer to the Ownership of Wetted land}

Farmers commitment in maintaining wetted land ownership status can not be separated from various internal and external factors. Internal factors were factors from inside the farmer such as the social value of wetted land, the width of wetted land, income from agricultural sector, education, farming experience, age, and number of household member involved in agricultural activities. External factors were factors from outside the farmers such as price of wetted land, access of wetted land to socio-economic facilities, 
and location of wetted land. Result of the statistic test using a multinomial logistic regression model indicates that the value of model fitting information that was seen from the statistic value of chi-square was 61,143 with p-value of 0.000 (Appendix 4). Because $\mathrm{p}$ value was $<0.05$, result of the statistic test indicates that the model used had a significant effect. It means that there was one of the internal and/or external factors influencing the level of farmer's commitment in maintaining wetted land ownership status The partial test was done to find out the partial effect of external and internal variables on the level of farmers commitment in maintaining wetted land ownership status. The test was done by seeking the $\beta$ value for each equation. Based on result of the test, the estimation indicates that the low level of farmer's commitment in maintaining wetted land ownership status was largely influenced by the price of wetted land, the social value of wetted land, and the location of wetted land. This was in line with the results of research done by Kurnianti et al, 2015 which found that the high conversion of agricultural land for settlement caused good access to the land's location.

The significant effect of the land price on farmers commitment in maintaining wetted land ownership status was caused by the increasing price of land, so the farmer's interest to divest the wetted land is increasing too, while the location of land greatly determined the economic value of land. For land which located near or directly connected to road, it will have greatly high economic values, particularly if the land was sold or sought for non-agricultural activities such as for settlement and non-settlement purposes. Meanwhile, the social value of wetted land was so significant because by the increasingly weak social binds between the farmers and wetted land, the farmer will weakly survive with the wetted land. It occurred because they regarded that the social value of wetted land was much lower than economic values resulted from wetted land commercialization.

\section{Acknowledgement}

Authors would like to thank LPPMUGM for providing fund of research through "Competitive Grants". The authors would also like to express gratitude to assistants who had helped collect the data at research locations.

\section{Conclusion}

The low farmer's commitment in maintaining wetted land ownership status could be seen from the low actions to prevent the desire of selling the land, renting out the land to peoples for non-agricultural purpose, and changing the land to be non-agricultural land. As a result, they will be easy to transfer the property right over wetted land by the selling-buying system, to transfer the function of wetted land to other people for non-agricultural use,,and to change the wetted land into non-agricultural one. The low farmer's commitment in maintaining wetted land ownership status was significantly affected by the land price, the social value of wetted land, and the location of wetted land.

\section{References}

Ilham (2003). Developments and Factors Affecting Land Conversion And Impact Rice Economy. IPB Press. Irawan, B., E. Husen, Maswar, R.L. Watung, \& F. Agus (2005). Perception and appreciation of the community on multifunctional agriculture: A case study in West Java and Central Java. Proceedings. Seminar Multifunctional Agriculture and Land Resource Conservation. Centre for Research and Development of Soil and Agro-climate. (pp. 21-43). Bogor. Jamal, E. (2001). Factors Affecting Land Price Formation Process Transfer Function Fields On the Use of Non Agricultural Land: A Case Study in Some Villages, Karawang regency. West Java. Agro-Economic Journal. 19(1):45-63.

Kurnianti Diya N., Ernan Rustiadi. \& Dwi Putro T.B, (2015). Land Use Projection for Spatial Plan Consistency in Jabodetabek. Indonesian Journal of Geography, 47(2), 124 - 131.

Nasoetion, L. \& J. Winoto (1996). Problems of Agricultural Land Transfer Function and Impact, the Sustainability of Food Self-Sufficiency. In Proceedings of the Workshop on Competition in the Land and Water Resource Utilization: Effects on Rice Self-Sufficiency Sustainability, Work together Socio-Economic Research Centre with the Ford Foundation, Bogor. Rahmanto B., (2006). Dampak Liberalisasi Perdagangan Global dan Perubahan Kondisi Ekonomi-Politik Domestik terhadap Dinamika Perdagangan Luar Negeri Kelompok Komoditas Berbasis Pertanian di Indonesia. Journal of socioeconomic and Agribusiness (SOCA). 6(2) , 1-23. Rusastra, I. W. \& G.S. Budhi (1997). Agricultural land conversion and anticipatory in Abatement Strategies. Journal of Agricultural Research and Development. XVI(4), 107 - 113.

Simatupang, P \& B. Irawan (2003). controls the conversion of agricultural land: A review perennial agricultural policy, National Seminar Papers Multifunction dan Agriculture Land Conversion, October 25, 2002, USDA Research Agency, Jakarta. Sudrajat (2010). Farmer Knowledge About Wetland Benefits And Implications For Environmental Commitment AgainstFarmerin Preventing Wetland Functions Rather, Proceedings IGI Seminar and Congress. University Surabaya country. Surabaya. Syafa'at, N., W. Sudana, N. Ilham, H. Supriyadi \& R. Hendayana (2001). Study Cause Decrease in Rice Production in Indonesia in 2001, Research Report: Analysis of Agricultural 
Development Policy Response to the Current Issues, Center for Research and Socio-Economic Development of Agriculture, Agricultural Research Agency, Ministry of Agriculture. Bogo Tajerin (2005). Factors Affecting Land Conversion Fishpond in East Java. Journal of Studies Indonesia: Social Humanities Studies, 15 (1). Yunus, H.S, (2001). Land Use Change in Suburban Areas: A Case outskirts of Yogyakarta. Dissertation. Faculty of Geography-Gadjah Mada University. Yogyakarta. 